\title{
Marital Adjustment and Depression among Couples
}

\author{
Sneh Lata $\mathrm{Rao}^{1} *$
}

\section{ABSTRACT}

The present study is aimed at exploring the relationship between marital adjustment and depression among couples. Sample of the study consisted of 26 couples. Their age ranged between 25 to 50 years. Their education was at least gradation and above. They belong to middle and high socio-economic status. Marital Adjustment questionnaire developed by Pramod Kumar and Kanchana Rohtagi and Beck Depression Inventory were used. Results indicated highly significant relationship between marital adjustment and depression. The findings of the results also show that both, women and men have to face more problems in their married life.

Keywords: Depression, Marital Adjustment, Couples, Family Structure

Marriage is a commitment with love and responsibility for peace, happiness and development of strong family relationships. One of the most important relationships between a man and women is marriage. It involves emotional and legal commitment that is quite important in any adult life. Moreover, selecting a partner and entering into a marital contract is considered both maturational milestone and personal achievement. There is no doubt that the choice of marital partner is one of the most important decisions one makes in his / her lifetime. People marry for many reasons, like; love, happiness, companionship, and the desire to have children, physical attraction, or desire to escape from an unhappy situation.”

Marriage as "socially legitimate sexual union, begun with a public announcement and undertaken with some ideas of permanence; it is assumed with more a less explicit marriage contract, which spells out the reciprocal rights and obligations between the spouses and children. Marriage is the key to whole some adjustment involvement and satisfaction. Marriage is our most common life style. One definition of adjustment is adaptation behavior that permits us to meet the demand of the environment. The person both husband and wife must learn to live together to share, compromise, accommodate, adjust and plan together. Marriage is more important in society to solve our social, cultural, personal and sexual problems. Landis (1954) Marriage and family are not optional they are necessary. They meet Maries deepest needs "Marriage provides a person an

\footnotetext{
${ }^{1}$ JRF, Department of Psychology, University of Lucknow, Lucknow, U.P., India

*Responding Author

Received: December 28, 2016; Revision Received: January 22, 2017; Accepted: February 2, 2017

(C) 2017 Rao S; licensee IJIP. This is an Open Access Research distributed under the terms of the Creative Commons Attribution License (www.creativecommons.org/licenses/by/2.0), which permits unrestricted use, distribution, and reproduction in any Medium, provided the original work is properly cited.
} 


\section{Marital Adjustment and Depression among Couples}

opportunity for a secure and protected satisfaction of his needs for companionship, affection and sexual expression. It involves the most intimate types of emotional relationship between two individuals. Journal of consulting and clinical psychology (1969) in marriage we take the positive for granted and focus on condemning the negative.

The study of past concepts in marital adjustment showed that it is permanently necessary for those processes of acquiring a balanced and functional marital relationship (Bradbury, Fincham and Beach, 2000). Grout and Clark (2001, Cited by Zadhoosh, 2008) Showed that couples who respond their needs in marital relationship such as sexual needs, they have more satisfaction.

Marital adjustment denotes emotional stability, intellectual efficiency and social effectiveness people. Marital adjustment as 'the state in which there is an overall feeling in husband and wife of happiness and satisfaction with their marriage and with each other. Marital adjustment calls for maturity that accepts and understands growth and development in the spouse. If this growth is not experienced and realized fully, death in marital relationship is inevitable. A relationship between couples is not instantaneous rather a slow progress. "It is like the undetected cancer that kills silently and softly”. A study on 581 couples and $25 \%$ of them disclosed that at some time in the adjustment process, they discussed discovering and 18\% had seriously considered it.

Locke \& Wallace defines marital adjustment as: "accommodation of husband and wife to each other at a given time”

According to Spanier and Cole, "Marital adjustment is a process, the outcome of which is determined by a degree of (a) troublesome marital differences (b) interpersonal tension and personal anxiety (c) marital satisfaction (d) dyadic cohesion (e) consensus on matters of importance of marital functioning.

The ultimate measurement of marriage is the degree of adjustment achieved by the individuals in their marriage roles and in interaction with one another. A well-adjusted marriage may be defined as a union in which the husband and wife are in agreement on the chief issue of marriage.

According to O.P. Mishra and S.K. Srivastava in marriage husband and wife should scarifies their egoistic attitude, to avoid mutual conflicts, feel mutual satisfaction, respect the each other interest and fulfils the expectations and aspiration related to marital life, all these will work in maintaining the good marital adjustment according to him the six dimensions of marital adjustment are: (a) Feeling for spouse (b) Harmonious relations (c) Communication (d) mutual understanding (e) sexual relations (f)other factors related to the marital life.

Comprehensive study of husbands and wives investigated some of the factors that contributed to marital satisfaction. Some of their findings revealed existing social, cultural, educational level 


\section{Marital Adjustment and Depression among Couples}

the greater satisfaction. Occupation and income, which are often thought to be associated with levels of satisfaction, have no relationship with it. The number of children too affects marital satisfaction. There is evidence that the pressures of managing multiple roles in women are the greatest, and the psychological benefits of employment are the least, under conditions of heavy family responsibilities that is, when young children are at home. But beyond specific factors such as these, what is important to marital satisfaction over the course of marriage is the ability of partner to adjust to a variety of changes and to cope with a number of stresses. Marital role can be defined as set of attitudes and behaviors a spouse is expired to demonstrate in the content of the marriage relationship. A marital role comprises cultural expectations associated with the husband or with a wife. A husband is expected to provide used is considered as head of family while wife is expected to make home and companion, or the wife may be expected to be the strong one, upon whom the husband can rely.

Perhaps half of the adults suffering from severe stress blame the deteriorating relationships on their spouse. Looking at the growing rate of divorces, court cases for alimony, physical abuses and single parents; it does seem as if handling a relationship can be a tricky and often taxing issue. The possible causes can be endless. More often than not, stress arising from marital relationships is manifested in chronic disorders such as depression, insomnia and hypertension. Since a relationship depends on the nature of the persons involved, it helps to seek the middle path when the inherent individual differences surface. It often helps to change one's attitude, go for counseling or talk openly with your spouse about problems facing your relationship.

Depression in a spouse is an issue that most couples will face at some point in their marriage. Depression is a normal and natural response to loss or grief, whether a death, separation from a loved one, job loss, loss of physical health, or relocation. Marital distress and relationship conflict also contribute to depression. Symptoms of depression include feelings of sadness, hopelessness, helplessness, anxiety, irritability, agitation, fatigue, low energy, and a reduced activity level are common, and there is also withdrawal from social contact and loss of interest in previously enjoyed activities, including sex. There may be changes in appetite, weight or sleep patterns, memory problems or difficulty concentrating. Often there are feelings of worthlessness or inadequacy and a lowered sense of self-esteem. In more serious cases there may be suicidal thoughts or a feeling that "life is not worth living" (Comer, 1996). Married women have higher rates of depression than unmarried women, but the reverse is true for men. Marriage seems to confer a greater protective advantage on men than on women. Marital adjustment and depression are strongly related. In a research, collected data on 695 women and 530 men and then reinterviewed them up to 1 year later. During this a number of participants separated from or divorced their spouses though the majority reported stable marriages. Approximately $21 \%$ of the women who reported marital split during the study experienced severe depression, a rate three times higher than that from women. Some facts of women's mental health are: 


\section{Marital Adjustment and Depression among Couples}

1. Recorded rate of anxiety and depression are one and a half to two times higher in women than in men.

2. One study showed that 57 percent o0f those attending emergency departments for self-harm are women.

3. $13-15 \%$ of new mothers experience postnatal depression.

4. $90 \%$ percent of the 1.6 million people in the U.K. who have an eating disorder are female.

\section{Objective of the Study}

The main objectives of the present study are as under

1. To study the effect of family structure on marital adjustment.

2. To find out the level of marital adjustment of women and men.

3. To find out the level of depression of women and men.

\section{Hypothesis of the Study}

1. There will be better marital adjustment in nuclear family for women and poor marital adjustment in joint family for women.

2. There will be better marital adjustment in joint family for men and poor marital adjustment in nuclear family for men.

3. There will be any significant mean difference on marital adjustment between women and men.

4. There will not be any significant difference on depression between women and men.

5. Highly significant correlation between marital adjustment and depression of couples.

\section{METHODOLOGY}

\section{Sample}

For the current study, a sample consisted of 26 couples (26 women and 26 men, N=52) with the marital life ranging 5-10 years residents of Vellore City, Chennai, India. The sample was further divided into two categories 13 couples (13 married women and 13 married men, $\mathrm{N}=26$ ) from joint family and 13 couples (13 married women and 13 married men, $\mathrm{N}=26$ ) from nuclear family. All the couples were selected middle class socio-economic strata with a minimum qualification (55\% Graduation and 45\% Post Graduation) they belonging to the urban (80\%) and rural (20\%) area. Mean age of women and men was 32.54 .

\section{Variable}

Independent variable: Marital Adjustment, Depression

Dependent variable: Women and Men. 


\section{Marital Adjustment and Depression among Couples}

\section{Inclusion and Exclusion}

The age range between of participants from 25 to 50 years. The minimum educational level of the graduation and they were selected from different socioeconomic backgrounds. The newly married couples were excluded from the present study.

\section{OPERATIONAL DEFINITION}

\section{Depression}

Depression is a mood disorder that can affect behavior and emotions. Symptoms of depression include feeling down most of the time, losing interest in previously enjoyable activities, increase or decrease in appetite or weight, sleeping more or less, becoming easily agitated or lethargic, feeling worthless, feeling guilty, having difficulty concentrating, thinking more about death and dying.

\section{Marital adjustment}

Marital adjustment is defined as the condition in which there is usually a feeling of pleasure and Contentment in husband and wife and with each other. (Hashmi, Khurshid, and Hassan, (2007).

\section{Instruments}

Following is a brief description of the tool used in the present study along with its psychometric properities. The personal data sheet used that collected demographic information such as name, age, gender, education, socio-economic status, nature of the family structure ,nature of job, marriage tenure, ecological area-rural/urban of the participants.

\section{Beck depression inventory (BDI)}

Beck Depression Inventory (BDI-II) given by Aaron D. Beck was used .The BDI-II is a selfreport measure of depression, consisting of 21 items that assess the severity of affective, behavioral, cognitive, and somatic symptoms of depression. Each item is scored on a 3-point scale. The reliability and validity of this test was very high i.e. .93.

\section{Marital adjustment Questionnaire}

The Pramod Kumar and Kanchana Rohtagi's Marital Adjustment scale is a simple measure of marital adjustment. The measure can be used as a brief screen to identify degree of marital adjustment. The scale involves 25 questions with dichotomous options (Yes / No). A 'yes' response is assigned a score 1 except for items 4, 10 and 19 in which case reverse is applicable. The sum of these values gives the marital adjustment score for the husband or the wife. Since the responses contributing towards marital adjustment are given a score, the higher the total score, the higher would be the marital adjustment of the husband or wife. 


\section{Marital Adjustment and Depression among Couples}

\section{Procedure}

In this study the above scale was used to assess marital adjustment and depression of the women and men .participants were selected through convenience sampling the scale was given to each participant individually and was administrated as per the standard printed with scale. The couples were approached at their houses and fill-up the questionnaire. The responses were recorded. The independent t-test, F-test and r were performed to test the present hypothesis of the study.

\section{RESULTS AND DISCUSSION}

In order to address the objective of the present study, F-test, t-test and $r$ was calculated and the findings have been tabulated

Table no. 1 Profile of Respondent

\begin{tabular}{|c|c|c|}
\hline Values & Frequency & Percentage \\
\hline married women & 26 & 50 \\
married men & 26 & 50 \\
\hline Age & & 45 \\
$50-41$ & 23 & 49 \\
$40-31$ & 25 & 6 \\
25-30 & 3 & 100 \\
\hline Marital Status & 52 & 0 \\
Married & 0 & 50 \\
Unmarried & & 50 \\
\hline Family Structure & 23 & 55 \\
Joint Family & 23 & 45 \\
Nuclear Family & 29 & \\
\hline Education & 23 & 50 \\
Above Graduation & 26 & 50 \\
Graduation & 26 & \\
\hline Socio Economic Status & & \\
4-5 Lakh & & \\
3-4 Lakh & & \\
\hline
\end{tabular}


Table no. 2 AB Interaction Table

\begin{tabular}{|c|c|c|c|}
\hline Marital Adjustment & \multicolumn{2}{|c|}{ Family Structure } & Total \\
\hline & $\mathbf{b}_{1}$ & $\mathbf{b}_{2}$ & 491 \\
\hline $\mathbf{a}_{1}$ & 238 & 253 & 511 \\
\hline $\mathbf{a}_{2}$ & 250 & 514 & $1002(\mathrm{G})$ \\
\hline Total & 488 & 514 & \\
\hline
\end{tabular}

The 2 Way ANOVA permits the study of two factor or variables. The first variable (Factor A) has two levels that are women and men, represented by a1 and a2 respectively. The second variable (Factor B) has two levels. That is joint \& nuclear family represented by b1 and b2 respectively.

Table No. 3 ANOVA scores of marital adjustment of Married Women and Men

\begin{tabular}{|l|l|l|l|l|}
\hline Source of variation & SS & df & MS & F \\
\hline A & 7.69 & 1 & 7.69 & 0.65 \\
\hline B & 13 & 1 & 13 & 1.09 \\
\hline AB & 0.30 & 1 & 0.30 & 0.03 \\
\hline Within Group (Error) & 574.24 & 48 & 11.97 & \\
\hline
\end{tabular}

F.99 $(1,48)=7.19$

F. $95(1,48)=4.04$

Results, Table -4 shows the summary table of 2 Way ANOVA, we have divided each of the sum of squares (SS) by the corresponding degrees of freedom (df) to obtain the mean of squares(MS).in the column headed $F$ the mean squares of $A, B, A B$ have been divided by the within group mean Squares (Error). The F ratio in respect of factor A has been found to be 0.65. We consult the F table, given in the Appendix, Table B for 1 and 48 degrees of freedom and observe that the critical value is 4.04 at .05 level and 7.19 at 0.01 levels. The observed value of 1.09, less the critical value at 0.05 and 0.01 level. Further we observe that the $F$ ratio in respect of factor $\mathrm{B}$ is $<.01$ levels, hence it is not significant. The AB interaction $\mathrm{F}$, based on 1 and $48 \mathrm{df}$, is found to be 0.03 . The critical value is 4.04 at 0.05 level and 7.19 at 0.01 levels. The observed value of $\mathrm{F}$ less the critical value. Results shows the no significant difference between marital adjustment and family structure so the our hypothesis (better marital adjustment in nuclear family for women and poor marital adjustment in joint family for women, better marital adjustment in joint family for men and poor marital adjustment in joint family for men, any significant mean difference on marital adjustment between women and men) reject. 
Marital Adjustment and Depression among Couples

Table No. 4 Means, Standard Deviations and t-value of Scores of Working and Non-working Married Women on BDI (Beck Depression Inventory)

\begin{tabular}{|c|c|c|c|}
\hline $\begin{array}{c}\text { Mean of Married Women } \\
(\mathrm{N}=26)\end{array}$ & $\begin{array}{c}\text { Mean of Married } \\
\text { Men }(\mathrm{N}=26)\end{array}$ & SD & $\mathrm{t}$ \\
\hline 23.77 & 24.46 & 3.64 & 2.38 \\
\hline
\end{tabular}

Results in table 4 show that there is non-significant difference between depression and working and non-working married women $(\mathrm{t}=2.38, \mathrm{df}=50, \mathrm{p}=\mathrm{n}$.s. at 0.05 level). The results indicate that married women and married men both have to face depression in their married life. Findings do not support our hypotheses that married women have to face more depression as compared to married men.

Table No. 5 Correlation Matrix of Scores of BDI (Beck Depression Inventory) and MAD (Marital Adjustment) (N=52)

\begin{tabular}{|c|c|}
\hline Scale & MDA \\
\hline BDI & $.50 * *$ \\
\hline
\end{tabular}

Results presented in the table 5 indicate that there is highly significant correlation between the two measures. The table also suggests that the correlation of BDI (Beck Depression Inventory) and MDA (Marital Adjustment) r=.50. It indicates that if depression is high in couples then their married life will be suffered. The hypothesis regarding this relationship is supported, which implies that higher the depression lower would be the marital adjustment.

\section{CONCLUSION}

The findings of the study indicate that working and non-working married women have to face more difficulties in their lives like they experienced more stress and depression. This study helpful in knowing just to spend a simple married life because our society is male oriented and women are suppose to face all the problems effectively. In Indian society both, men and women play a pivotal role and their roles may be defined based on their cultural values and societal norms. Marital adjustment has been related to personality, job and home stress, mental illness, depression, education, sex role attitudes, happiness and success in life.

\section{Acknowledgments}

The author appreciates all those who participated in the study and helped to facilitate the research process.

Conflict of Interests: The author declared no conflict of interests. 


\section{REFERENCES}

Baniasadi, H. (2002). The study of some social and personal factors on marital adjustment. Human science magazine, special edition for psychology A study of marital adjustment in relation to...www.ijhssi.org page.10

Best John, W. (1963), Research in education. New - Delhi: Prentice Hall of India Pvt. Ltd.

Bradbury, T. Fincham, F. \& Beach, S. (2000). Research on the nature and determinants of marital satisfaction: A decade in review. Journal of Marriage and Family.

Dalack, G.W., 1990, Perspectives on the Relationship between Cardiovascular Disease and Affective Disorder. The Journal of Clinical Psychiatry ;51:4-9

Hashmi HA, Khurshid M, Hassan I. (2007).Marital Adjustment, Stress and Depression among Working and Non-Working Married Women. Internet Journal of Medical Update, Vol.,2(1), pp.:19-26.

Kalpana, D. B.;Pravin, A. B., (2013). A study of marital adjustment in relation to some psychosocio factor. International Journal of Humanities and Social Science, Volume 2 Issue 6, PP. 08-10, Invention ISSN (Online):2319-7722, ISSN (Print):2319-7714www.ijhssi.org.

Kumar, P., \& Rohtagi, K. (1984). Certain personality correlates of marital adjustment. Indian Journal of Social Work, 45, 325-330.

Kumar, P., \& Rohtagi, K. (1985). Marital adjustment: Study of some personality correlates. Indian Journal of Clinical Psychology, 12, 15-18.

Locke, H. J., \& Wallace, K. M., 1959, Short marital-adjustment and prediction tests: Their reliability and validity. Marriage and Family Living, 21, 251-255.

Mishra, O.P. and Srivastava, S.K., 1997, Comprehensive Marital Adjustment Inventory (CMAI), Published by Ajay printers and publishers, Rurkee, U.P.

Sinha, S.P. and Mukherjee, N., 1990, Marital adjustment and space orientation, The journal of social Psychology, 130 (5) 633-639.

Spainer, G.B. and Cole, C.L., 1976, Towards classification investigation of marital adjustment. International Journal of Sociology of the Family.

Thakar, M. (2010). Sexual self disclosure, relationship satisfaction, body image and sexual satisfaction among married women. An unpublished M.Phil dissertation Saurashtra University.

How to cite this article: Rao S (2017), Marital Adjustment and Depression among Couples, International Journal of Indian Psychology, Volume 4, Issue 2, No. 87, ISSN:2348-5396 (e), ISSN:2349-3429 (p), DIP:18.01.045/20170402, ISBN:978-1-365-71287-6 